\title{
UPAYA PERCEPATAN PENYEMBUHAN LUKA PERINEUM PADA IBU POST PARTUM DENGAN ANTISEPTIK DAUN SIRIH DI PUSKESMAS WAGIR KABUPATEN MALANG
}

\author{
Ririn Harini \\ Fakultas IImu Kesehatan Universitas Muhammadiyah Malang \\ E-mail : ri2nharini@gmail.com
}

\begin{abstract}
Perineal rupture cannot be considered a mild problem because it can result in the emergence of serious complications including bleeding, severe pain, secondary infection, birth canal deformity. The goal of perineal care can be to prevent infection, prevent contamination of the rectum, treat traumaaffected tissue, clean sources of bacteria and odors. The purpose of this study was to determine the differences in healing of perineal wounds in post partum mothers with betel leaf antiseptic. This type of experimental research with post-test design only non random design. Total sample of 20 people divided into intervention and control groups. Sampling technique with purposive sampling. The results of the pretest tabulation data showed that 7 respondents (70\%) had first-degree injuries and 3 respondents (30\%) had second-degree injuries, in the use of antiseptic betadine respondents with perineal wounds treated with antiseptic betel leaves there were 4 respondents (40\%) have a grade 2 wound and 6 respondents (60\%) have a grade 3. wound then Ho was rejected so that it can be interpreted that the treatment of betel leaf wounds is more effective than with betadine on the healing of perineal wounds in post partum mothers.
\end{abstract}

\section{Keywords : Wound Healing, Post Partum, Sirih Leaves}

\begin{abstract}
Abstrak : Ruptur perineum tidak dapat dianggap sebagai masalah ringan karena bisa berakibat timbulnya penyulit yang serius di antaranya dapat terjadi perdarahan, nyeri hebat, infeksi sekunder, deformitas jalan lahir. Tujuan perawatan perineum dapatmencegah infeksi, mencegah kontaminasi dari rektum, mengatasi jaringan yang terkena trauma, membersihkan sumber bakteri dan bau. Tujuan penelitian ini untuk mengetahui Perbedaan penyembuhan luka perineum pada ibu post partum dengan antiseptic daun sirih. Jenis penelitian Experimental dengan rancangan post test only non random design. Jumlah sampel 20 orang yang terbagi dalam kelompok intervensi dan kelompok kontrol dengan teknik purposive sampling. Hasil tabulasi data pre test diperoleh data bahwa 7 responden (70\%) memiliki luka derajat 1 dan 3 responden (30\%) memiliki luka derajat 2, pada penggunaan antiseptik betadine responden dengan luka perineumnya yang dirawat dengan antiseptik daun sirih terdapat 4 responden $(40 \%)$ memiliki luka derajat 2 dan 6 responden $(60 \%)$ memiliki luka derajat 3 . Pada hasil analisis uji-t diperoleh nilai $t$-hitung $(10,08)$ dan nilai tabel $(2,20)$ sehingga nilai t terletak diluar daerah penerimaan Ho, maka Ho ditolak sehingga dapat diinterpretasikan bahwa perawatan luka dengan daun sirih lebih efektif dari pada dengan betadine terhadap penyembuhan luka perineum pada ibu post partum.Peneliti menyarankan kepada petugas kesehatan hendaknya lebih memperhatikan perawatan perineum pada ibu post partum dengan teknik septik dan antiseptik.
\end{abstract}

Kata Kunci : Penyembuhan Luka, Ibu Post Partum, Daun Sirih

\section{PENDAHULUAN}

Proses persalinan merupakan suatu proses fisiologis yang dipengaruhi oleh beberapa faktor lain fisik atau tenaga ibu (power), jalan lahir (passage), janin (passager), psikologi ibu dan penolong. Faktor jalan lahir mempunyai peranan penting baik sebelum maupun sesudah proses persalinan. Persalinan seringkali mengakibatkan robekan jalan lahir, robekan tersebut terjadi hampir pada semua persalinan pertama kali dan tidak jarang juga pada persalinan kedua dan seterusnya, di mana robekan perineum ini dapat terjadi secara spontan atau melalui insisi bedah (episotomi). Robekan perineum ini tidak dapat dianggap sebagai masalah ringan, lebih-lebih robekan yang spontan bisa berakibat timbulnya penyulit yang serius di antaranya dapat terjadi perdarahan, nyeri hebat, infeksi sekunder, deformitas jalan lahir. Mengingat banyaknya permasalahan yang dapat timbul sebagai akibat robekan jalan lahir pada saat melahirkan, maka penanganan setiap kejadian robekan jalan lahir harus segera dilakukan secara berkualitas, guna meminimalkan kemungkinan penyulit yang bisa menyertai 
robekan jalan lahir tersebut (Hamimah, 2006).

Tujuan perawatan perineum menurut Hamilton (2002), adalah mencegah terjadinya infeksi sehubungan dengan penyembuhan jaringan. Selain itu perawatan luka yang baik dapat mencegah kontaminasi dari rektum, menangani dengan lembut pada jaringan yang terkena trauma serta dapat membersihkan semua keluaran yang menjadi sumber bakteri dan bau.

Pada saat ini teknik perawatan luka perineum itu bisa dilakukan dengan antiseptik seperti betadine maupun dengan tanaman obat keluarga (TOGA) seperti daun sirih. Dari hasil penelitian sebagaimana dikutip oleh buku tanaman obat terbitan kebun tanaman obat karyasari (Santoso Budi, 2006) diungkapkan bahwa sirih mengandung tannin pada daunnya yang bermanfaat mengurangi sekresi cairan pada vagina dan mencegah infeksi pada daerah sekitar vagina. Manfaat daun sirih yang lain adalah untuk obat kulit dan luka yang memiliki khasiat antiseptik.

Dalam melakukan perawatan luka dengan antiseptik yang dalam hal ini betadine sudah sering dilakukan di daun sirih rumah sakit atau pelayanan kesehatan yang lain sedangkan perawatan luka dengan masih jarang dilakukan di suatu institusi pelayananpelayanan kesehatan. Hal ini terjadi karena banyak orang yang tidak tahu manfaat dan kandungan dari daun sirih.

\section{METODE PENELITIAN}

Jenis penelitian Experimental dengan rancangan post test only non random design. Populasi yang akan diambil dalam penelitian ini adalah ibu post-partum yang sedang kontrol luka perineumnya di Puskesmas Wagir Kabupaten Malang. Sedangkan jumlah sampel dalam penelitian ini adalah 20 orang yaitu 10 orang kelompok yang diberi antiseptik pada lukanya dan 10 kelompok perlakuan berikutnya diberi daun sirih pada luka perineumnya.

Tehnik sampling yang digunakan dalam penelitian ini adalah purposive sampling. Kriteria sampel adalah ibu-ibu post partum yang sedang kontrol di Puskesmas Wagir, bersedia menjadi responden, melahirkan secara normal. Penelitian ini
Menurut Santoso budi (2006), bahwa daun sirih itu mengandung minyak terbang (betlephenol), sesekuirtepen, pati, diatase, gula, zat samak dan chavicol yang memiliki daya mematikan kuman, antioksidan, fungisida dan anti jamur, sehingga dapat menyembuhkan luka di daerah manapun apalagi daerah perineum. Tradisi lain dari manfaat daun sirih juga sering digunakan wanita untuk membersihkan daerah sekitar vagina setiap pagi dan sore, sehingga produksi lendir yang berlebihan dapat teratasi. Membersihkan atau mencuci luka apapun terutama perineum dengan 8-10 lembar daun sirih yang sudah direbus dengan $1 / 2$ ember air dan dilakukan secara teratur pagi dan sore akan dapat menghilangkan rasa gatal-gatal dan mempercepat penyembuhan luka. Berdasarkan uraian tersebut di atas maka peneliti tertarik untuk meneliti bagaimana upaya percepatan penyembuhan luka perineum pada ibu post partum dengan antiseptik daun sirih. Hasil penelitian ini diharapkan dapat digunakan sebagai bahan informasi / guideline bagi dunia kesehatan dan masyarakat dalam melakukan perawatan kesehatan sehingga dapat dicapai penyembuhan luka

Adapun tujuan penelitian ini untuk mengetahui perbedaan proses penyembuhan luka perineum jika diberi antiseptik daun sirih dengan antiseptic betadin pada ibu post partum.

dilaksanakan di Puskesmas Wagir dan dilaksanakan dalam waktu selama 3 (tiga) bulan April - Juni 2011. Penelitian dilakukan pada ibu post partum dengan menggunakan lembar observasi pad ibu yang luka perineumnya dirawat dengan antiseptic betadin maupun dengan daun sirih. Masingmasing responden diobservasi selama lima hari yang dimulai pada hari pertama post partum dengan menggunakan instrumen Bourbonnais.

\section{HASIL}

Upaya percepatan penyembuhan luka perineum pada ibu post partum dengan antiseptik daun sirih di wilayah kerja Puskesmas Wagir Kabupaten Malang. Hasil penelitian ini disajikan dalam bentuk tabel. 
Tabel 1 Karateristik ibu berdasarkan usia

\begin{tabular}{ccc}
\hline UMUR & \multicolumn{3}{c}{ Jumlah Prosentase } \\
\cline { 2 - 3 } & N & $\%$ \\
\hline 19 tahun & 3 & 15 \\
20 tahun & 4 & 20 \\
21 tahun & 2 & 10 \\
2 tahun & 5 & 25 \\
24 tahun & 4 & 20 \\
25 tahun & 1 & 5 \\
Jumlah & 1 & 5 \\
\hline
\end{tabular}

Berdasarkan tabel di atas, dijelaskan bahwa dari 20 ibu yang dilibatkan dalam penelitian, sebanyak 3 orang atau sekitar $15 \%$ ibu berusia antara 19 tahun. Sebanyak 4 orang atau sekitar $20 \%$ ibu berusia 20 tahun.Sebanyak 2 orang atau sekitar $10 \%$ ibu berusia 21 tahun. Sebanyak 5 orang atau sekitar $25 \%$ ibu berusia 22 tahun. Sebanyak 4 orang atau sekitar $20 \%$ ibu berusia 23 tahun. Sebanyak 1 orang atau sekitar $5 \%$ ibu berusia 24 tahun. Dan sisanya sebanyak 1 orang atau sekitar $5 \%$ ibu berusia 25 tahun.

Tabel 2 Karakteristik Ibu berdasarkan Pendidikan

\begin{tabular}{ccc}
\hline \multirow{2}{*}{ Pendidikan } & \multicolumn{2}{c}{ Frekuensi } \\
\cline { 2 - 3 } & $\mathbf{N}$ & $\%$ \\
\hline SD & 5 & 25 \\
SMP & 11 & 55 \\
SMA & 4 & 20 \\
\hline & $\mathbf{2 0}$ & $\mathbf{1 0 0}$ \\
\hline
\end{tabular}

Berdasarkan Tabel.2, dijelaskan bahwa dari 20 ibu yang dilibatkan dalam penelitian, sebanyak 5 orang atau sekitar $25 \%$ ibu berpendidikan terakhir SD. Sebanyak 11 orang atau sekitar $55 \%$ ibu berpendidikan terakhir SMP. Dan sisanya sebanyak 4 orang atau sekitar $20 \%$ ibu berpendidikan terakhir SMA.

Tabel 3. Karakteristik Ibu berdasarkan Jenis Pekerjaan

\begin{tabular}{ccc}
\hline \multirow{2}{*}{ Pendidikan } & Frekuensi \\
\cline { 2 - 3 } & N & $\%$ \\
\hline SD & 5 & 25 \\
SMP & 11 & 55 \\
SMA & 4 & 20 \\
\hline & $\mathbf{2 0}$ & $\mathbf{1 0 0}$ \\
\hline
\end{tabular}

Berdasarkan tabel 3, dijelaskan bahwa dari 20 ibu yang dilibatkan dalam penelitian, sebanyak 8 orang atau sekitar $40 \%$ ibu berprofesi sebagai ibu rumah tangga. Dan sisanya sebanyak 12 orang atau sekitar $60 \%$ ibu berprofesi sebagai buruh pabrik.

Tabel 4 Karakteristik Ibu berdasarkan Penyembuhan Luka

\begin{tabular}{ccc}
\hline \multirow{2}{*}{ Penyembuhan Luka } & \multicolumn{2}{c}{ Frekuensi } \\
\cline { 2 - 3 } & $\mathbf{N}$ & $\%$ \\
\hline Betadine & 10 & 50 \\
Daun Sirih & 10 & 50 \\
\hline Jumlah & 20 & 100 \\
\hline
\end{tabular}


Berdasarkan tabel 4, dijelaskan bahwa dari 20 ibu yang dilibatkan dalam penelitian, sebanyak 10 orang atau sekitar $50 \%$ ibu menggunakan antiseptik jenis betadine untuk penyembuhan luka. Dan sisanya sebanyak 10 orang atau sekitar $50 \%$ ibu menggunakan daun sirih untuk penyembuhan luka.

\section{PEMBAHASAN}

Berdasarkan penelitian tentang upaya percepatan penyembuhan luka perineum pada ibu post partum dengan antiseptic daun sirih di wilayah kerja puskesmas wager malang pada bula April-Juni 2011, peneliti melakukan responden (70\%) memiliki luka derajat 1 dan 3 responden (30\%) memiliki luka derajat 2, pada penggunaan antiseptik betadine. Sedangkan pada responden yang luka perineumnya dirawat dengan antiseptik daun sirih terdapat 4 responden (40\%) memiliki luka derajat 2 dan 6 responden (60\%) memiliki luka derajat 3.Menurut Teori

Hamilton (2002) bahwa perawatan perineum bertujuan mencegah terjadinya infeksi sehubungan dengan penyembuhan jaringan. Selain itu perawatan luka yang baik dapat mencegah kontaminasi dari rektum, menangani dengan lembut pada jaringan yang terkena trauma serta dapat membersihkan semua keluaran yang menjadi sumber bakteri dan bau. Proses penyembuhan luka membutuhkan peran dari perawat dalam melakukan rawat luka dengan teknik septik dan antiseptik serta mempertimbangkan keadaan umum dari luka pasiennya. Perhatian dan kepedulian dari perawat juga dapat mempengaruhi psikologis dari pasien, sehingga jika pasien bahagia sehingga lekas sembuh lukanya.

Dari hasil analisis uji-t yang diperoleh dengan rancangan "Pre dan Post test desain, sesuai hipotesa penelitian yang sudah ditetapkan oleh peneliti. Karena nilai t-hitung $(10,085)$ dan nilai tabel $(2,201)$ sehingga nilai

\section{KESIMPULAN DAN SARAN}

Hasil observasi (pre test) sebelum dilakukan perawatan luka, diperoleh data bahwa 20 responden (100\%) mempunyai keadaan derajat luka 2 dan 3 baik pada responden yang akan dirawat dengan antiseptik betadine maupun dengan antiseptic daun sirih. Dari hasil pelaksanaan perawatan luka dengan betadine dapat diketahui bahwa lama proses penyembuhan luka perineum pada ibu post partum lebih lama ( \pm 2 hari) jika dibandingkan dengan $\mathrm{t}$ terletak diluar daerah penerimaan Ho, maka Ho ditolak dan dapat diinterpretasikan bahwa perawatan luka dengan daun sirih lebih efektif dari pada dengan betadine terhadap penyembuhan luka perineum pada ibu post partum. Berdasarkan teori dari Mirzal Tarwi,2008. Bahwa membersihkan atau mencuci luka apapun terutama perineum dengan 8-10 lembar daun sirih yang sudah direbus dengan $1 / 2$ ember air dan dilakukan secara teratur pagi dan sore akan dapat menghilangkan rasa gatal-gatal dan mempercepat penyembuhan luka.

Penyembuhan luka merupakan suatu proses yang kompleks karena observasi (pre test) dan diperoleh data bahwa 10 responden (50 \%) diberikan antiseptic betadin dan 10 responden $(50 \%)$ berikutnya diberikan antiseptic daun sirih dalam perawatan luka perineumnya.Sedangkan hasil tabulasi data pre test diperoleh data bahwa 7 berbagai kegiatan bioseluler, biokimia terjadi berkesinambungan.

Penggunaan respons vaskuler, aktivitas seluler dan terbentuknya bahan kimia sebagai substansi mediator di daerah luka merupakan komponen yang saling terkait pada proses penyembuhan luka. Besarnya perbedaan mengenai penelitian dasar mekanisme penyembuhan luka dan aplikasi klinik saat ini telah dapat diperkecil dengan pemahaman dan penelitian yang berhubungan dengan proses penyembuhan luka dan pemakaian bahan pengobatan yang telah berhasil memberikan kesembuhan.

menggunakan antiseptik daun sirih. Perawatan luka dengan daun sirih lebih efektif daripada dengan betadine terhadap penyembuhan luka perineum pada ibu post partum di puskesmas Wagir Kabupaten Malang.

Petugas kesehatan diharapkan lebih memperhatikan bagaimana melakukan perawatan perineum pada ibu post partum dengan baik sesuai teknik septik dan antiseptik dengan mempertimbangkan 
keadaan umum dari pasien serta mensosialisasikan pada masyarakat bahwa daun sirih juga bisa menjadi salah satu alternative bahan antiseptik yang bisa

\section{DAFTAR PUSTAKA}

Arikunto Suhartini (1998). Prosedur Penelitian. Jakarta : PT. Rineka Cipta

Arikunto, Suharsini. 2002. Prosedur Penelitian : Suatu Pendekatan Praktek Edisi Revisi V. Jakarta: Rineka Cipta

Budi Santoso, Hierinymus.2006.Toga 2 Tanaman Obat Keluarga. Yogyakarta:Kanisius

Dorothy \& Marie.Tanpa tahun. Dasar-dasar Riset Keperawatan Edisi 2. Terjemahan oleh Yasmin dan Aniek. 1999. Jakarta: EGC.

Kozier,B. Erb,G.\& Oliveri,R. 1991. Fundamental of Nursing: Concept, Process, and Practice. 4th edition: The Benjamin/Cummings Publishing Co.Inc. California

Long, Barbara C. 1996. Perawatan Medikal Bedah. EGC. Jakarta

Nursalam. 2001. Pendekatan Praktis Metodologi Riset Keperawatan. Jakarta: CV. Sagung Seto.

Nursalam. 2003. Konsep dan Penerapan Metodologi Penelitian IImu Keperawatan. Pedoman Skripsi, Tesis dan Instrumen Penelitian digunakan untuk rawat luka perineum asalkan diproses dulu dengan cara yang bersih, steril dan benar.

Keperawatan. Salemba Medika. Jakarta

Prawirohardjo, Sarwono. 2007.Ilmu Bedah Kebidanan.Jakarta: Yayasan Bina Pustaka Sarwono Prawirohardjo.

Pusat Bahasa Departemen Pendidikan Nasional. 2001. Kamus Besar Bahasa Indonesia. Jakarta: Balai Pustaka.

Redaksi Agromedia, 2008. 273 Ramuan Tradisional untuk Mengatasi Aneka Penyakit. Jakarta: PT.Agromedia Pustaka.

Santoso,S. 2003. Buku Statistik Non Parametrik. PT Elex Media Komputindo. Jakarta

Smeltzer, Susanne dan Bare, Brenda. 2002. Buku Ajar Keperawatan Medikal Bedah. Ed.8 Vol.1, EGC, Jakarta

Soekidjo Notoatmojo (1998). Metode Penelitian Kesehatan. Jakarta : PT. Rineka Cipta.

Sudewo, Bambang. 2005. Basmi Penyakit dengan Sirih Merah. Jakarta : PT.Agromedia.

Sugiyono. 2005. Statistika Untuk Penelitia Alfabeta. 